\title{
難治性疼痛に対する脊髄刺激療法
}

\author{
上利 崇1), 伊達 勲 ${ }^{2)}$ \\ 1）倉敷平成病院倉敷ニューロモデュレーションセンター，2）岡山大学大学院脳神経外科
}

\section{Spinal Cord Stimulation for Intractable Pain}

\author{
Takashi Agari, M.D., Ph.D. ${ }^{1)}$, and Isao Date, M.D., Ph.D. ${ }^{2)}$
}

1) Center for Neuromodulation, Kurashiki Heisei Hospital, 2) Department of Neurological Surgery, Okayama University Graduate School of Medicine, Dentistry and Pharmaceutical Sciences

Spinal cord stimulation (SCS) is a well-established treatment modality for refractory chronic pain. The factors that are significant in assuring the success of this therapy include appropriate patient selection, stimulation site, and stimulation method. SCS has a significant analgesic effect on peripheral neuropathic pain and ischemic pain. Although a detailed mechanism of the action of SCS has not been elucidated, proper stimulation of the dorsal column of the spinal cord is thought to be necessary for obtaining an analgesic effect. The optimal placement of electrodes is of great importance, that is, these should be sufficiently covering the pain area. Recently, new waveform types for SCS(ultra high-frequency stimulation and burst stimulation) have become available, and good outcomes have been reported with a high level of evidence.

(Received March 11, 2019; accepted April 10, 2019)

Key words : neuropathic pain, burst stimulation, spinal cord stimulation

Jpn J Neurosurg (Tokyo) $28: 334-341,2019$

\section{はじめに}

春髄刺激療法（spinal cord stimulation：SCS）は，難治 性の慢性疼痛に対する治療として，脊䯣硬膜外腔に電極 を留置し, 脊髄後索 (dorsal column：DC) を中心に電気 刺激を行い, 疼痛の緩和を図る治療法である。1965 年の Melzack と Wall ${ }^{16)}$ による太い線維 $(\mathrm{A} \beta$ 線維) が細い線維 （Aס，C 線維）の痛覚情報の伝達を抑制するという gate control theory に基づき，1967 年 Shealy $ら^{21)}$ にり末期 癌患者に対して, DC 刺激が行われたのが最初である。 現在では難治性慢性疼痛に対して確立した治療選択肢の

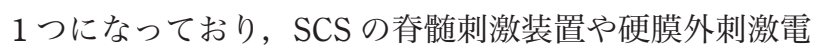
極のめざましい進歩に伴い, 治療成績の向上と適応疾患
の拡大が期待される（Fig. 1)。一方で，治療機器の発展 にもかかわらず，これまでの SCS の治療効果には 40 年 間大きな差がないともいわれている ${ }^{32)}$ 。その要因として は, SCS の作用機序が明確でなく，適応や治療手段に混 乱があったことが挙げられる。

本稿ではこれまで明らかとなっているSCSの作用機 序と, 最適な治療効果を得るために必要な患者選択や治 療手段について解説し，最近になって使用可能となった 新しい刺激方法である高頻度刺激，バース卜刺激の臨床 上の特徴について紹介する。

連絡先：上利 崇， テ 710-0826 倉敷市老松町 4-3-38 倉敷平成病院倉敷ニューロモデュレーションセンター Address reprint requests to: Takashi Agari, M.D., Ph.D., Center for Neuromodulation, Kurashiki Heisei Hospital, 4-3-38 Oimatsu-cho, Kurashiki-shi, Okayama 710-0826, Japan 


\begin{tabular}{lllllllll}
\hline 1999 & 2006 & 2010 & 2012 & 2013 & 2014 & 2016 & 2017 & 2019 \\
\hline
\end{tabular}

System

Maximum number of electrodes that can be used 4 8 16

Additional features

$$
\begin{aligned}
& \text { Automatic position- } \\
& \text { adaptive stimulation }
\end{aligned}
$$

Multiple independent current control

Full-body MRI compatible

Low frequency tonic stimulation

High-frequency tonic stimulation $(1 \mathrm{kHz})$
Burst stimulation

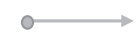

Fig. 1 A schematic summarizing the improvement of the SCS system over the past two decades

\section{慢性疼痛における脊髄後角の機能異常}

慢性疼痛においては, 痛覚過敏が認められるが, 脊髄 後角（dorsal horn：DH）内での疼痛伝導路の機能的な異 常がその 1 要因となる。侵害刺激を伝える一次ニューロ ン $(\mathrm{A} \delta, \mathrm{C}$ 線維 $)$ のシナプス前において興奮性神経伝達 物質（グルタミン酸, サブスタンス P) の放出が充進し た状態となり，さらにシナプス後においても二次ニュー ロンのNMDA受容体の感受性に変化が生じ, 過敏状態と なる，さらに周囲のグリア細胞が活性化することで炎症 物質を放出することで, シナプス間の興奮伝達を常に促 進した状態となっている。これらの状態は中枢性感作と 呼ばれており, DH 第 5 層に存在する広作動域（wide dynamic range: WDR) ニューロンの過敏性, 感受性変化 が慢性疼痛の持続，増悪に深く関わっていると考えられ ている。また, 触刺激の入力を受ける $\mathrm{A} \beta$ 線維の分枝が DH 内に異所性に発芽し疼痛伝導路につながることで, 触感覚が痛みの感覚として知覚されるアロディニア（異 痛症）を生じるようになる。

\section{従来の SCS（トニック刺激）の作用機序}

SCS の鎮痛効果の機序に関しては，いまだ完全に解明 されていないが，現在のところ DC の刺激により太い有 髄線維 $(\mathrm{A} \beta$ 線維 $)$ が脱分極し, 双方向性に刺激が伝導
することで DH に対して以下の 2 つの機序で鎮痛効果を 発揮すると考えられている ${ }^{15)}($ Fig. 2)。(1)順行性伝導に よる作用機序 (supraspinal mechanism) : 刺激が DC の軸 索を順行性に上行し，中枢において下行性疼痛抑制系を 賦活化することで, DH 内のWDRニューロンの異常活動 を抑制する。(2)逆行性伝導による作用機序（segmental mechanism) : DC の刺激が逆行性に伝導し, $\mathrm{A} \beta$ 線維の側 副枝を介して，分節性に DH 内の抑制性介在細胞を活性 化し，WDRニューロンを抑制する，または $\mathrm{A} \beta$ 線維の後 根（dorsal root：DR）内を伝わり，より末梢に作用する と考えられている。

神経障害性疼痛の動物モデルにおいて, DH の WDR ニューロンの異常な発火活動はSCSによって抑制さ $れ^{31)}$ ，持続的刺激に対する DH 内 wind up 現象の抑制も 認められる ${ }^{29)}$. DH内での細胞外 GABA 濃度は増加し ${ }^{24)}$, グルタミン酸濃度の減少が認められる ${ }^{6)}$. GABAb 受容体 はシナプス前に存在し, グルタミン酸の放出抑制に働く が, GABAb 受容体拮抗薬では, SCS の効果が減弱するこ とから SCS は GABA システムを介して WDRニューロン を抑制すると考えられる7)。また最近では GABA 以外に も，アセチルコリン ${ }^{20)}$ やアデノシン ${ }^{7)}$ の関与, NMDA 受 容体のサブタイプの発現減少 ${ }^{25)}$ ，オピオイド受容体の活 性化 ${ }^{19)}$, グリア細胞活性化の抑制 ${ }^{18)}$ が認められている. 


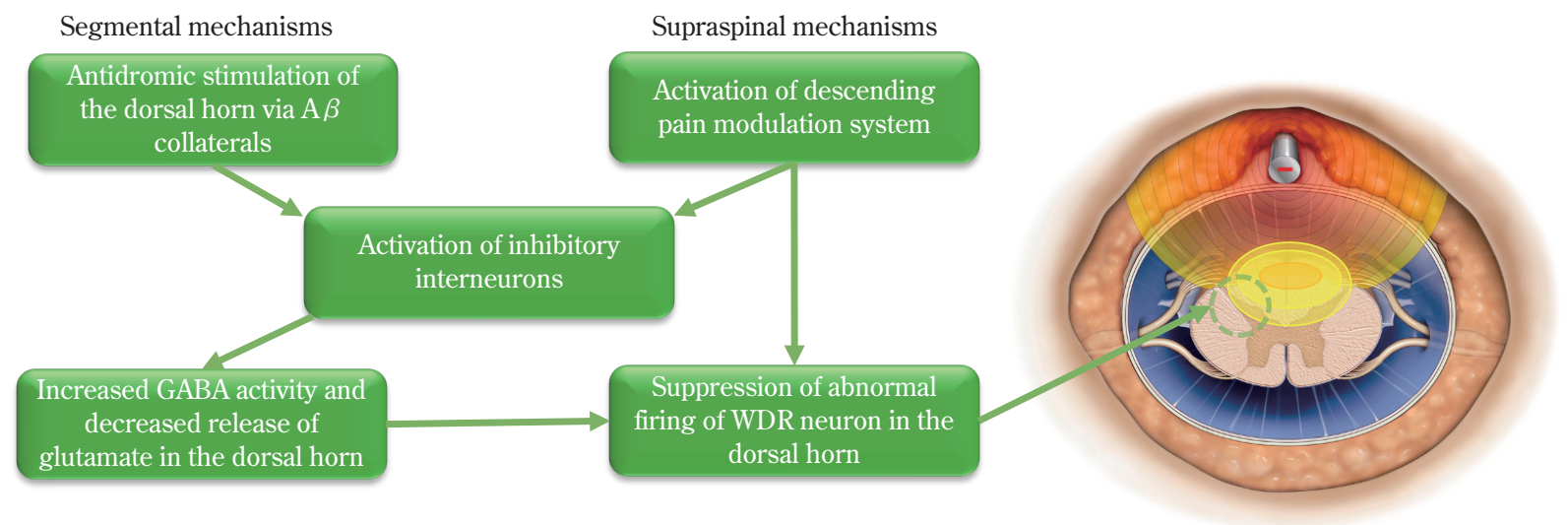

Fig. 2 A schematic showing the known segmental and supraspinal mechanisms involved in conventional SCS when applied for neuropathic pain

Antidromic stimulation of DC afferents induces the activation of inhibitory interneurons in the dorsal horns, and orthodromic stimulation in DCs activates the neurons in the rostral ventromedial medulla (RVM) and locus coeruleus (LC) in the brainstem, leading to descending pain inhibition.

Table 1 Indications for SCS adapted from the British Pain Society Guideline

\begin{tabular}{l|l}
\hline $\begin{array}{l}\text { Good } \\
\text { Likely to respond) }\end{array}$ & $\begin{array}{l}\text { Neuropathic pain in leg or arm following lumbar or cervical spine surgery (FBSS/FNSS) } \\
\text { Complex regional pain syndrome (CRPS) } \\
\text { Neuropathic pain secondary to peripheral nerve damage } \\
\text { Pain associated with peripheral vascular disease }\end{array}$ \\
& $\begin{array}{l}\text { Refractory angina pectoris (RAP) } \\
\text { Brachial plexopathy : traumatic (partial, not avulsion), post-irradiation }\end{array}$ \\
\hline $\begin{array}{l}\text { Intermediate } \\
\text { (May respond) }\end{array}$ & $\begin{array}{l}\text { Amputation pain (stump pain responds better than phantom pain) } \\
\text { Axial pain following spinal surgery } \\
\text { Intercostal neuralgia, such as post-thoracotomy or post-herpetic neuralgia }\end{array}$ \\
& $\begin{array}{l}\text { Pain associated with spinal cord damage } \\
\text { (other peripheral neuropathic pain syndromes, such as those following trauma may respond) }\end{array}$ \\
\hline Poor & $\begin{array}{l}\text { Central pain of non-spinal cord origin } \\
\text { (Rarely respond) }\end{array}$ \\
& $\begin{array}{l}\text { Spinal cord injury with clinically complete loss of posterior column function } \\
\text { Perineal or anorectal pain }\end{array}$ \\
\hline Unresponsive & $\begin{array}{l}\text { Complete spinal cord transection } \\
\text { Non-ischaemic nociceptive pain } \\
\text { Nerve root avulsion }\end{array}$ \\
\hline
\end{tabular}

\section{SCS が有効な疼痛症候群}

現在，本邦では慢性の難治性疼痛に対して幅広い適応 があるが，これまでの経験から神経障害性疼痛または， 虚血性疼痛に対し治療効果が高いとされる。疼痛の原因 疾患によって, SCSの治療効果は異なり, British Pain Societyの 2009 年のガイドラインでは各疼痛症候群に対 して推奨レベルが示されており, SCS 適応決定の際に参 考となる ${ }^{3)}$ (Table 1). SCS の作用機序を考えると, DC ま たはDH の機能がある程度保たれていないと，SCS の有 効性は発揮されないと考えられる。つまり脊髄より末梢
レベルの病変に対して SCS の有効性は高く, 一方で春髄 性またはそれより上位の中枢性病変に対するSCS の治 療効果は乏しい.

\section{SCS の適応と患者選択}

SCS の適応基準を Table 2 に示す ${ }^{2)}$. 神経障害性疼痛で は痛覚過敏, 知覚低下, 触・圧・温冷刺激によるアロディ ニアの出現を認める. 疼痛の原因に心理社会的要因が強 く関与する場合は, SCS の鎮痛効果は乏しく, SCS 治療 が適さない。患者の心理社会的問題となる背景を十分に 
Table 2 Criteria for identifying patients suitable for the consideration of SCS (adapted from Atkinson et al., 2011)

1) Diagnosis of pain Neurogenic pain pathology is the basis of pain complaint

Clear diagnosis of neuropathic pain is evident, although accompanying nociceptive pain may be present

2) Failure of conservative treatment

Pain releif is insufficient despite adequate conventional treatments $(>3$ months $)$

Further corrective surgical intervention not indicated

3) Patient-related aspects

Therapy goals have been established

No significant unmanaged psychological issues present

No serious drug or chemical substance dependence or abuse

4) SCS-related aspects

No surgical contraindications to implantation

Satisfactory results from SCS trial

5) Device control \& follow-up

Patient can properly operate system

Implantation centre and hospital staff are educated, familiar and willing to participate as a team

把握し, 慎重な患者選択を行う必要がある. 試験刺激( ト ライアル）に関しては，50\%以上の鎮痛効果が得られた 場合に刺激装置の埋め込みを行った後の SCS の治療成 績がよいといわれている。デバイスの進歩により，患者 が疼痛管理を適切な条件で行えるようになったが，その 反面, 機器の煩雑さは増しており, 認知機能低下がある 患者では，SCS の有効な実施が困難である．介護者も治 療に参加し, 機器の操作について指導する必要がある.

\section{適切な SCS の治療手技}

実際の臨床では，SCS の DC 刺激により，触覚の皮膚 求心性神経が刺激されて局所的な刺激誘発感（パレステ ジア）が誘発され，このパレステジアが疼痛領域を十分 にカバーすることが，鎮痛効果に必要である．刺激電極 を脊髄硬膜外腔の正中に留置すると, その脊髄高位レべ ルょりは尾側の広範囲なパレステジアが得られ，電極が 外側に位置すると, 1 ないし 2 分節のパレステジアが得 られる。 DRが直接刺激されると DR 内を通過する Ia の 求心性神経が低い閾值で活性化し, 単シナプス反射経路 を介して, 筋収縮が生じやすく, 鎮痛が得られるパレス テジアを発現させられない場合が多い，そのため広範囲 にパレステジアを得るために，つまり DC を選択的かつ 広範囲に刺激を行うために, 電極を脊䯣の正中もしくは 傍正中に留置することが基本となる (Fig. 3)。電極留置 部位の高位レベルに関しては, 疼痛部位および知覚障害 を呈しているデルマトームを参考にし，該当する脊髄分 節よりも中枢側に留置する。刺激電極に関しては，陰極
が周囲の組織を脱分極させて刺激部位となり，陽極は過 分極させる。通常，DC の長軸方向の隣接した電極間で の刺激を基本とする．DCに対する陰極の位置により， 刺激部位が片側または両側に変化する（Fig. 3A，B）。複 数の電極りードを並列に配置すると，並列した電極を陰 極と陽極にするか (トランスバース刺激)，複数の電極を 陰極にし（ダブルカソード）刺激をすることで DC に対 し側方性の刺激の調整が可能となる (Fig. 3C)。 また DC をより選択的に刺激する場合には陰極周囲に複数の陽極 を配置し，刺激が及ぶ範囲の絞り込みを行う（ガーデッ ドカソード）（Fig. 3D）。このように種々の組み合わせを 試み，疼痛領域を十分カバーするような刺激電極の選択 を行う。刺激条件は，刺激頻度が $2 \sim 40 \mathrm{~Hz}$ ，パルス幅は 200 500 $\mu \mathrm{sec}$ で, パレステジアが心地よく感じる刺激 強度に調整する。刺激頻度は患者のパレステジアの好み に関与し，パルス幅，刺激強度はパレステジアの出現範 囲に影響する。

\section{SCS の治療効果のエビデンス}

脊椎手術後疼痛症候群 (failed back surgery syndrome： FBSS）に関しては，神経障害性要因の強い疼痛に対して 有効であり，手術が不十分な例はもとより，除圧が十分 に行えている例でも疼痛の主な原因が，神経損傷など神 経に起因すると考元られる場合には積極的な適応とな る．FBSS の神経障害性疼痛を主とする下肢痛に対する ランダム化比較試験では，SCS 治療群は薬物・理学療法 単独群や再手術群と比較して，50\%以上の疼痛抑制効果 

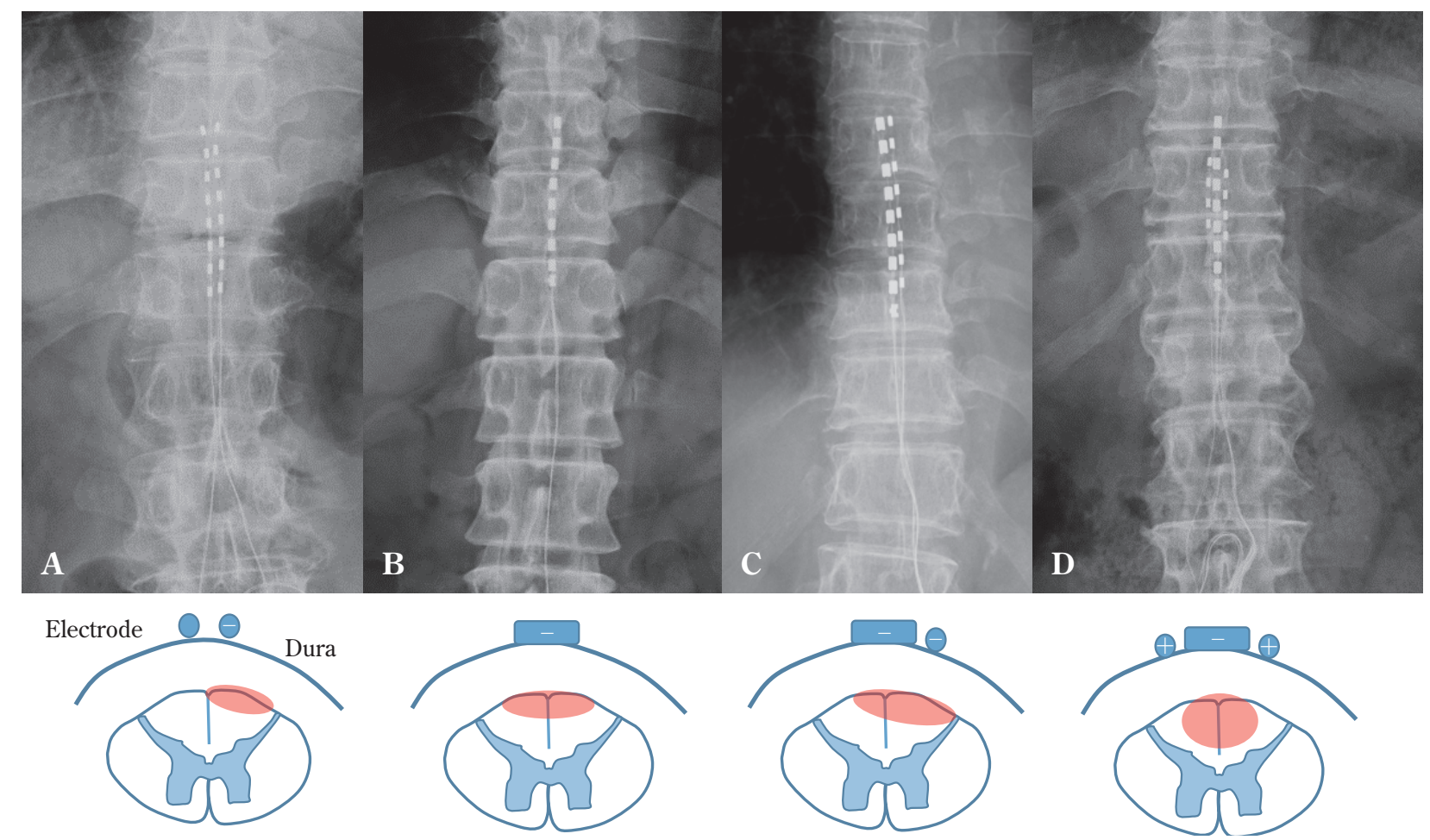

Fig. 3 Illustrative examples of electrode placement

A : The dual-lead placement can steer the stimulation localized in the horizontal direction of DC.

B : The percutaneous paddle lead can stimulate DC selectively above the midline of DC.

C : The combination of the percutaneous paddle and cylindrical leads can steer lateralized stimulation in DC.

D : The transverse tripolar stimulation ("guarded cathode"stimulation) is capable of activating DC selectively without activation of DR.

が有意に高く, QOL の向上および薬物の減量が得られ, 中長期にわたり疼痛抑制効果が維持された ${ }^{13) 14) 17)}$.

重症虚血肢（critical limb ischemia：CLI）の疼痛に対 し, SCS は有効であり, また SCS は末梢循環改善作用が あり，下肢温存への効果も期待される. SCSの CLI の疼 痛および末梢循環改善に対する作用機序についても明確 ではないが，刺激が $\mathrm{A} \beta$ 線維を末梢まで逆行性に伝導す ることで，血管拡張物質である CGRP (calcitonin generelated peptide）の放出が起こる, また交感神経の抑制に より $\alpha 1$ 受容体の減少が起こり, 血管拡張が生じるなど の機序が考えられている ${ }^{30)}$. CLI の適切な適応は(1)Fontaine: III度, Rutherford：II -4 以上の PAD で安静時疼痛 を認め，(2)血行再建の適応がないか，または不可能であ り，(3)末梢微小循環がある程度保たれており〔経皮的酸 素分圧 $\left(\mathrm{TcPO}_{2}\right)$ で $10 \mathrm{mmHg}$ 以上], (4)潰瘍はあっても $3 \mathrm{~cm}$ 以下で非感染例である. 過去のランダム化比較試験 では, CLI の疼痛に対しては有効であるものの, 下肢温 存に対する有効性は, 薬物療法や他の治療法と比較し て, 有意差がない研究が多かったが, システマティック
レビューでは下肢温存に対する有効性も示された ${ }^{27)}$. 術 前に末梢微小循環がある程度保たれていれば，下肢温存 率が上昇するといわれており ${ }^{28)}$, 下肢切断に至った場合 でもその切除範囲を最小限に留めることが期待できる.

\section{新しい刺激方法 \\ （超高頻度刺激,バースト刺激）の特徵}

近年, 従来の刺激方法（トニック刺激）とは別に，新 しい刺激方法である超高頻度 $(10 \mathrm{kHz})$ 刺激 (ネルボ 社), バースト刺激 (アボット社)を行える刺激装置が開 発され，海外では使用されている。本邦ではこのうち バースト刺激を行う刺激装置が 2017 年 5 月から使用可 能となった。バースト刺激は脳内のニューロンの生理的 なバースト発火活動に似せた刺激であり，周波数は 40 $\mathrm{Hz}$ で，5つのパルスからなっており, バースト内の周波 数は $500 \mathrm{~Hz}$ で，パルス幅㧍よびパルス間隔が $1 \mathrm{msec}$ 秒 である（Fig.4）。

超高頻度刺激, バースト刺激の両者に共通する臨床的 


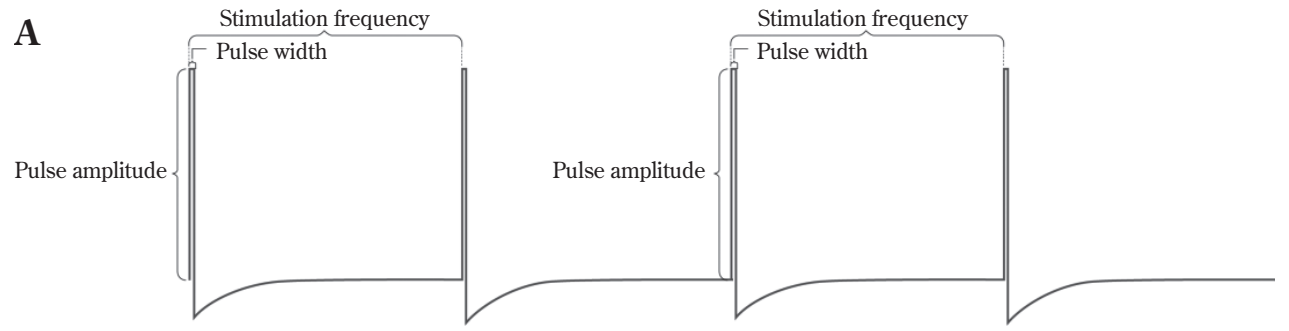

B

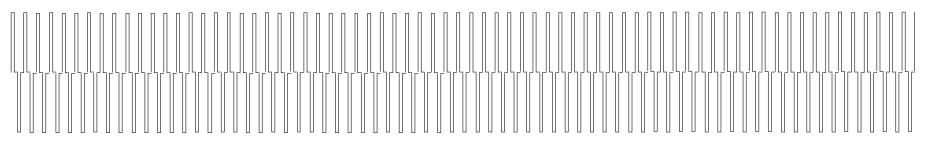

C

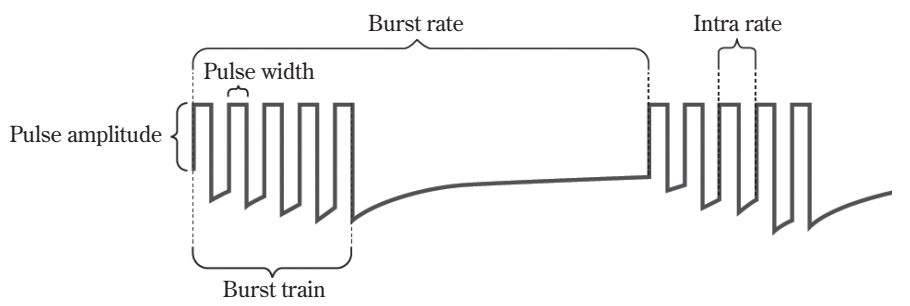

Fig. 4 New waveforms in SCS

A : Conventional low-frequency "tonic"stimulation.

B : Ultra high-frequency $(10 \mathrm{kHz})$ stimulation.

C : Burst stimulation.

特徴は, SCS により誘発されるパレステジアがなくて も，鎮痛効果が得られることである ${ }^{8)}$. 従来のトニック 刺激では, 刺激が疼痛部位以外の体部位に及ぶと, 不快 感が生じたり, 体位変化によって, パレステジアの強弱 の変化がみられたりするため, 刺激の調整に苦慮する場 合がある. パレステジアフリーの新しい刺激方法では, これらの問題を気にすることなく，刺激を広範囲に及ば せることで, 疼痛部位を十分にカバーすることが可能と なっている.

治療効果においても超高頻度刺激やバースト刺激で は，従来のトニック刺激では治療効果がそしかった軸性 疼痛を主体とする神経障害性疼痛に対して良好な鎮痛効 果が得られたエビデンスレベルの高い報告がなされてい る ${ }^{11) 12)}$. さらにバースト刺激では, トニック刺激の効果 が減弱した症例に対してもバースト刺激に切り替えるこ とで再度鎮痛効果を発揮することが報告されている ${ }^{9)}$.

本邦では超高頻度刺激のデバイスは使用できないた め, $1,200 \mathrm{~Hz}$ までの高頻度刺激を用いる場合がある。動 物実験においては $1 \mathrm{kHz}$ と $10 \mathrm{kHz}$ とで鎮痛効果に違いが なかったものの ${ }^{22)}$, 臨床では $5 \mathrm{kHz}$ を超す高頻度の刺激 により鎮痛効果が得られたと報告されている ${ }^{1)}$. 高頻度 刺激, バースト刺激の電極の留置部位, 電極選択に関し ては低頻度トニック刺激と同様であるが，DC の正中刺 激を行うべきである。刺激強度は知覚されるパレステジ
アの閾值の 60〜80\%以下に設定する.

超高頻度刺激の鎮痛機序については, 解明されていな い. 軸索に対して可逆的な伝導ブロックを起こすことが 想定されたが，実際の臨床では刺激幅は狭く，刺激振幅 も低いため, DC の軸索に対して遮断や活性化も生じな いとされておりその作用機序は不明である ${ }^{523)}$.

バースト刺激の作用機序も現時点で不明である。神経 障害性疼痛の動物実験において, DH 内の GABA システ ムを介さずにWDRニューロンの抑制が得られており また上位中枢に対しては, 薄束核の自発発火の変化がな く鎮痛効果を発揮することから ${ }^{26)}$, DC の順行性伝導を 介して中枢に影響しない可能性があり，トニック刺激と は作用機序が異なると考えられる。上位中枢への作用機 序に関しては, 慢性疼痛患者での SCS 刺激中の脳波解析 により, バースト刺激がトニック刺激よりも内側系, 外 側系, 下行性疼痛抑制経路に対して強い影響を与えるこ とが示唆されており, バースト刺激は DH において C 線 維由来の WDR ニューロンを直接刺激し, 同期化した バースト発火活動を抑制することで, 内側疼痛経路を調 節しているという仮説が立てられている ${ }^{10)}$.

\section{おわりに}

最適な SCS の治療効果を得るためには, 適切な手術適 
応と治療手技が求められる。治療抵抗性の神経障害性疼 痛または虚血性疼痛を主体とする疼痛症候群を適応と し，DC 刺激によって疼痛部位を十分カバーするように 電極留置を行う必要がある。新しい刺激方法である超高 頻度刺激やバース卜刺激はこれまで SCS の治療の限界 とされた軸性疼痛に対しても有効であり, 従来のSCS の 限界を超えた治療効果の向上が期待される.

著者全員は日本脳神経外科学会への $\mathrm{COI}$ の自己申告を完了 しています。本論文に関して開示すべき COI はありません。

\section{文 献}

1) Al-Kaisy A, Palmisani S, Pang D, Sanderson K, Wesley S, Tan Y, McCammon S, Trescott A : Prospective, randomized, sham-control, double blind, crossover trial of subthreshold spinal cord stimulation at various kilohertz frequencies in subjects suffering from failed back surgery syndrome (SCS Frequency Study). Neuromodulation 21: 457-465, 2018.

2) Atkinson L, Sundaraj SR, Brooker C, O'Callaghan J, Teddy P, Salmon J, Semple T, Majedi PM : Recommendations for patient selection in spinal cord stimulation. J Clin Neurosci 18: 1295-1302, 2011.

3) British Pain Society : Spinal cord stimulation for the management of pain: recommendations or best clinical practice. 2009. http://www.britishpainsociety.org/book_scs_main. pdf

4) Crosby ND, Weisshaar CL, Smith JR, Zeeman ME, Goodman-Keiser MD, Winkelstein BA : Burst and tonic spinal cord stimulation differentially activate GABAergic mechanisms to attenuate pain in a rat model of cervical radiculopathy. IEEE Trans Biomed Eng 62: 1604-1613, 2015.

5) Crosby ND, Janik JJ, Grill WM : Modulation of activity and conduction in single dorsal column axons by kilohertz-frequency spinal cord stimulation. J Neurophysiol 117: 136$147,2017$.

6) Cui JG, O'Connor WT, Ungerstedt U, Linderoth B, Meyerson $\mathrm{BA}$ : Spinal cord stimulation attenuates augmented dorsal horn release of excitatory amino acids in mononeuropathy via a GABAergic mechanism. Pain $\quad$ 73: 87-95, 1997.

7) Cui JG, Meyerson BA, Sollevi A, Linderoth B : Effect of spinal cord stimulation on tactile hypersensitivity in mononeuropathic rats is potentiated by simultaneous GABA (B) and adenosine receptor activation. Neurosci Lett 247 : 183186, 1998.

8) De Ridder D, Vanneste S, Plazier M, van der Loo E, Menovsky T : Burst spinal cord stimulation : toward paresthesia-free pain suppression. Neurosurgery $65: 986^{-990}$, 2008.

9) De Ridder D, Lenders MW, De Vos CC, Dijkstra-Scholten C, Wolters R, Vancamp T, Van Looy P, Van Havenbergh T, Vanneste S: A 2-center comparative study on tonic versus burst spinal cord stimulation: amount of responders and amount of pain suppression. Clin J Pain 31:433-437, 2015.

10) De Ridder $D$, Vanneste $S$ : Burst and tonic spinal cord stimulation: different and common brain mechanisms. Neuromodulation 19: 47-59, 2016.
11) Deer T, Slavin KV, Amirdelfan K, North RB, Burton AW, Yearwood TL, Tavel E, Staats P, Falowski S, Pope J, Justiz R, Fabi AY, Taghva A, Paicius R, Houden T, Wilson D : Success using neuromodulation with BURST (SUNBURST) study : results from a prospective, randomized controlled trial using a novel burst waveform. Neuromodulation 21:56-66, 2018.

12) Kapural L, Yu C, Doust MW, Gliner BE, Vallejo R, Sitzman BT, Amirdelfan K, Morgan DM, Brown LL, Yearwood TL, Bundschu R, Burton AW, Yang T, Benyamin R, Burgher $\mathrm{AH}$ : Novel $10-\mathrm{kHz}$ high-frequency therapy（HF10 therapy) is superior to traditional low-frequency spinal cord stimulation for the treatment of chronic back and leg pain: the SENZA-RCT randomized controlled trial. Anesthesiology 123: 851-860, 2015.

13) Kumar K, Taylor RS, Jacques L, Eldabe S, Meglio M, Molet J, Thomson S, O'Callaghan J, Eisenberg E, Milbouw G, Buchser E, Fortini G, Richardson J, North RB : Spinal cord stimulation versus conventional medical management for neuropathic pain : a multicentre randomised controlled trial in patients with failed back surgery syndrome. Pain 132 : 179-188, 2007.

14) Kumar K, Taylor RS, Jacques L, Eldabe S, Meglio M, Molet J, Thomson S, O'Callaghan J, Eisenberg E, Milbouw G, Buchser E, Fortini G, Richardson J, North RB : The effects of spinal cord stimulation in neuropathic pain are sustained : a 24-month follow-up of the prospective randomized controlled multicenter trial of the effectiveness of spinal cord stimulation. Neurosurgery $\quad 63: 762-770,2008$.

15) Linderoth B, Foreman RD : Conventional and novel spinal stimulation algorithms : hypothetical mechanisms of action and comments on outcomes. Neuromodulation 20:525533, 2017.

16) Melzack R, Wall PD : Pain mechanisms : a new theory. Science 150: 971-979, 1965.

17) North RB, Kidd DH, Farrokhi F, Piantadosi SA : Spinal cord stimulation versus repeated lumbosacral spine surgery for chronic pain : a randomized, controlled trial. Neurosurgery 56: 98-106, 2005.

18) Sato KL, Johanek LM, Sanada LS, Sluka KA: Spinal cord stimulation reduces mechanical hyperalgesia and glial cell activation in animals with neuropathic pain. Anesth Analg 118: 464-472, 2014.

19) Sato KL, King EW, Johanek LM, Sluka KA: Spinal cord stimulation reduces hypersensitivity through activation of opioid receptors in a frequency-dependent manner. Eur J Pain 17: 551-561, 2013.

20) Schechtmann G, Song Z, Ultenius C, Meyerson BA, Linderoth $\mathrm{B}$ : Cholinergic mechanisms involved in the pain relieving effect of spinal cord stimulation in a model of neuropathy. Pain 139: 136-145, 2008.

21) Shealy CN, Mortimer JT, Reswick JB : Electrical inhibition of pain by stimulation of the dorsal columns : preliminary clinical report. Anesth Analg 46: 489-491, 1967.

22) Shechter R, Yang F, Xu Q, Cheong YK, He SQ, Sdrulla A, Carteret AF, Wacnik PW, Dong X, Meyer RA, Raja SN, Guan $\mathrm{Y}$ : Conventional and kilohertz-frequency spinal cord stimulation produces intensity- and frequency-dependent inhibition of mechanical hypersensitivity in a rat model of neuropathic pain. Anestheology $\quad 119$ : 422-432, 2013.

23) Song $Z$, Viisanen H, Meyerson BA, Pertovaara A, Linderoth $B$ : Efficacy of kilohertz-frequency and conventional spinal 
cord stimulation in rat models of different pain conditions. Neuromodulation 17:226-234, 2014.

24) Stiller CO, Cui JG, O’Connor WT, Brodin E, Meyerson BA, Linderoth B : Release of gamma-aminobutyric acid in the dorsal horn and suppression of tactile allodynia by spinal cord stimulation in mononeuropathic rats. Neurosurgery 39: 367-374, 1996.

25) Sun L, Tai L, Qiu Q, Mitchell R, Fleetwood-Walker S, Joosten EA, Cheung CW : Endocannabinoid activation of CB1 receptors contributes to long-lasting reversal of neuropathic pain by repetitive spinal cord stimulation. Eur J Pain 21: 804-814, 2017.

26) Tang R, Martinez M, Goodman-Keiser M, Farber JP, Qin C, Foreman RD : Comparison of burst and tonic spinal cord stimulation on spinal neural processing in an animal model. Neuromodulation 17:143-151, 2014.

27) Ubbink DT, Vermeulen $H$ : Spinal cord stimulation for nonreconstructable chronic critical leg ischaemia. Cochrane Database Syst Rev, CD004001, 2005.
28) Ubbink DT, Vermeulen $\mathrm{H}$ : Spinal cord stimulation for critical leg ischemia : a review of effectiveness and optimal patient selection.J Pain Symptom Manage 31 (4 Suppl) : S30-35, 2006.

29) Wallin J, Fiskå A, Tjølsen A, Linderoth B, Hole K : Spinal cord stimulation inhibits long-term potentiation of spinal wide dynamic range neurons. Brain Res $\mathbf{9 7 3}: 39-43$, 2003.

30) Wu M, Linderoth B, Foreman RD : Putative mechanisms behind effects of spinal cord stimulation on vascular diseases : a review of experimental studies. Auton Neurosci 138: 9-23, 2008.

31) Yakhnitsa V, Linderoth B, Meyerson BA : Spinal cord stimulation attenuates dorsal horn neuronal hyperexcitability in a rat model of mononeuropathy. Pain $\quad 79: 223-233,1999$.

32) Zhang TC, Janik JJ, Grill WM : Mechanisms and models of spinal cord stimulation for the treatment of neuropathic pain. Brain Res $1569: 19-31,2014$.

\section{難治性疼痛に対する脊骵刺激療法}

\section{上利 崇 伊達 勲}

難治性の慢性疼痛に対して, 脊髄刺激療法（spinal cord stimulation：SCS）は有効な治療選択肢の 1 つである. 最適な治療効果を得るのに重要なのは, 適切な患者選択, 刺激部位および刺激方法であ る. 霄髄以下の末梢の神経障害性疼痛および虚血性疼痛に対して SCS が奏効することが多い. SCS の作用機序の詳細は解明されていないが, 脊剈造後索を適切に刺激することが鎮痛効果の発現に重要で あると考えられている. 電極留置では疼痛部位を十分カバーするように留置する必要がある. 最近で は新世代型 SCS（超高頻度刺激, バースト刺激）が行われるようになり, エビデンスレベルの高い治 療効果も報告されている. 